\title{
Accuracy Analysis of Enterprise Internal Control - IT System Audit (Alibaba)
}

\author{
Xiyue Zhang ${ }^{1, *}$ \\ ${ }^{1}$ School of pennon, Qingdao, Shandong Province, China \\ *Corresponding author. Email: ${ }^{a}$ guanghua.ren@gecacademy.cn
}

\begin{abstract}
In the early 1960s, the concept of information systems was initially developed and introduced in the United States in the mid-1960s. With the progress of society, IT audit is also constantly developing and applied to major enterprises. This paper takes the company with problems in IT system audit as an example to analyse and summarizes the problems existing in its system audit of our country in the stage, such as putting forward effective solutions, lacking talent, inadequate management. This article puts forward an effective solution to avoid the same problems in the enterprise again so that the company's interests are affected. It puts forward some suggestions for the control of IT system audit, technical guidance for personnel and upgrades in hardware. This paper uses the case analysis method to discuss and describe the information technology audit, analyses Alibaba, and finds that the audit will lead to the stock price decline, the company will make great changes.
\end{abstract}

\section{Keywords: Internal controls, Information technology system, audit}

\section{INTRODUCTION}

China's Internet from 1994 to 2017 experienced a total of three Internet waves, from the search of the four major portals to the launch of WeChat, enough to prove that China's Internet development speed is extremely fast. Second, some companies will choose certified public accountants and bribery in the audit process, making the audit process more unfair, but IT audit will not be such a situation. IT audit is an information system audit, independent of the information system itself, information-related system development, and personnel of the third party. From the mid-to-late 1970s to the early $1980 \mathrm{~s}$, due to the initial popularity of computers in developed countries, the use of computer crime and computer system failures frequently appear, so that IT audit has been increasingly paid attention to by the community. The 1990 s were a popular period for IT auditing, thanks in large part to the popularity of the Internet. This article shows that if an enterprise is overaudited, it can have a huge impact. It can even lead to a re-break in internal management. A small percentage of innocent people may pay for audit errors.

In modern society, some enterprises do not care about internal audits leading to a series of problems. Companies that are immature or unwilling to hire thirdparty auditors in the internal audit department will experience adverse conditions for the business, such as falling stocks, changes in internal management, and corporate failures. In general, internal audit has a significant impact on companies, including information technology audits and the hiring of certified public accountants.

This paper mainly uses the case study method by analysing Alibaba's share price falling before the company went public. Further extends to whether it is related to the reasons for the immaturity of information technology audits. At the end of the article, the findings are mentioned: the lack of information technology audit talent, it audits system lack of management and enterprises do not pay attention to internal audit. The article is not entirely accurate because there is not a lot of research.

This paper analyses the problems of Alibaba's internal audit is an example and puts forward some suggestions for the development of its audit. The second part of the article mainly introduces the reasons for the internal control of the enterprise and the background of its audit. The differences between the two audit methods (hiring a certified public accountant and an information technology audit) are mainly compared in the third part. Then, Alibaba company as the main body of analysis and in the fifth part of the internal audit of the 
enterprise's problems and recommendations. Finally, the article is further summarized and summarized.

\section{LITERATURE REVIEW}

Internal control of an enterprise is a series of activities in which an enterprise adopts effective supervision over its financial, human, asset, and work processes to ensure its management activities' normal, orderly and lawful operation. The internal control of an enterprise requires ensuring the accuracy, authenticity, effectiveness and timeliness of the enterprise's assets and financial information, ensuring effective control over the employees, workflow, and logistics of the enterprise, and establishing an effective supervision mechanism for the business activities of the enterprise.

The IT systems application brings great benefits to enterprise operation, and the information construction helps enterprises collect and transmit business data information quickly and accurately. This allows the enterprise to quickly adjust and organize firms' production to meet companies' production needs as quickly and efficiently as possible, so that enterprises can adapt to consumers as quickly as possible, and reduce the additional costs associated with traditional business transactions. Gray [1] examine the internal auditing function's (IAF's) use of integrated IT auditing and provide evidence of how internal auditors' IT audit activities contribute to IT governance, a critical subset of corporate governance. Importantly, increased understanding of these IT audit practices assists educators in curriculum design reflective of practitioner needs. Bazerman [2] assesses the current impact of technology on the audit process and discusses the future implications of technological trends for the auditing profession. More specifically, provides a summary of how information technology has impacted audit planning, testing, and documentation. Janvrin's [3] descriptive study explores audit IT use and its perceived importance across several audit applications. To address regulator concerns about barriers to entry in public accounting and to advance auditing research. Bierstaker [4] assesses the current impact of technology on the audit process and discusses the future implications of technological trends for the auditing profession. More specifically, provides a summary of how information technology has impacted audit planning, testing, and documentation. While this article also has a great shortcoming: domestic and foreign major websites can refer to fewer references, less practical application, so inevitably there will be less thorough research aspects in the process of research. There are still more experiments that should be done to make the results more accurate.

\section{THE WAY FOR A FIRM'S AUDITING}

\subsection{Hire Certified Public Accountant}

CPA audit is also an independent audit, which refers to the activities of CPA to accept entrustment, practice independently and provide professional services to the society for a paid amount of time. Certified public accountant, audit comes from the separation of property ownership and management rights. The establishment of the audit system of certified public accountants is an inevitable requirement for China to implement the reform and opening-up policy and establish the socialist market economy system, which plays an important role in promoting reform and opening-up and economic development. The complexity of the organization, business unit, or process, will play an important role in the Controls to monitor other controls, including activities of the internal audit function, the audit Because of its importance to financial reporting and the auditor's opinions on internal control [5]. When companies hire certified public accountants, they are asked to audit THEIR IT systems first. During the audit process, employees can demonstrate their control over information technology and improve their professionalism through the use of information technology. Secondly, the construction of an information system can improve the efficiency of the audit. However, there are some disadvantages to hiring a certified public accountant, as there may be violations of CPA ethics, such as the possibility of an employment relationship with a certified customer. And this kind of behaviour according to the "China Certified Public Accountants Professional Ethics Code Guidance" is several content targeted ways to deal with.

\subsection{Online audit}

The importance of information technology (IT) auditing has grown with increased reliance on IT for business operations and new regulations regarding the assurance of IT for these operations [6]. Network audit refers to the auditor based on the Internet, with the help of modern information technology, the use of specialized methods, through the combination of human and machine, the audited unit's network accounting information system development process and its compliance, reliability and effectiveness, as well as the authenticity and legitimacy of network-based accounting information remote audit. Online audit refers to the auditing organ and the audited unit after the network interconnection, based on the evaluation of the audited unit's financial management information system and efficient data collection and analysis, the audited unit's financial income and expenditure of real, legal, effective real-time, remote inspection and supervision behaviour. With the continuous development of the Internet, IT audit is becoming more and more common, 
more listed companies are looking at the fairness of IT audit, which will not receive artificial influence leading to information modification. Meanwhile, IT audit and general audit are still very different, even if the basic concepts and procedures and architecture are generally consistent. However, IT audit has two innovations: first, security audit: In a traditional audit, the security of audited objects is rarely involved, and the security of information is related to the survival and development of enterprises, is an important guarantee to maintain the healthy and sustainable development of enterprises. Security audits are regulated in detail in IT audits.

The main purpose of a security audit is to review the security risks of enterprise information systems and electronic data. It is difficult for an information system with security risks to provide real and reliable information to auditors, so a security audit is also the premise of an authenticity audit.

Secondly, it is the software test method and the electronic forensic method of IT audit: the audit method runs through the whole audit process, not just exists in a certain audit stage or a certain link. With the enrichment of IT audit system practice and the development of IT audit theory, IT audit processing uses traditional audit methods and a lot of reference to some computer science methods for this paper's use. Among them, "software test method" is one of the important methods of IT system audit, the more classical test method is black box test and white box test.

In addition, certain accounting data and other information can only exist electronically, or only at a certain point in time or period, and access to such electronic data is critical at the time of an IT audit, ensuring that IT auditors discover and collect sufficient and reliable electronic evidence to produce audit reports. Although various information technologies have been studied using the technology acceptance model (TAM), the study of acceptance of specific technology features for professional groups employing information technologies such as internal auditors (IA) have been limited [7].

\section{CASE STUDY}

Some listed companies in our country have problems with their companies because of the consideration of issues, such as Alibaba. Alibaba's share price fell sharply on February 22nd, voluntarily admitting that the company had a problem with fraud in the early stages of development. The root of this problem is that the audit of enterprises is not close to the phenomenon.

The hiring of third-party, certification companies will involve cost issues, and Internet audit application is difficult. Thus, the internal audit cannot meet the standards. Then the enterprise problems happen. Using IT audits can significantly reduce this and prevent corporate interests from being compromised. It firstly gives the stock trend of Alibaba as follows.

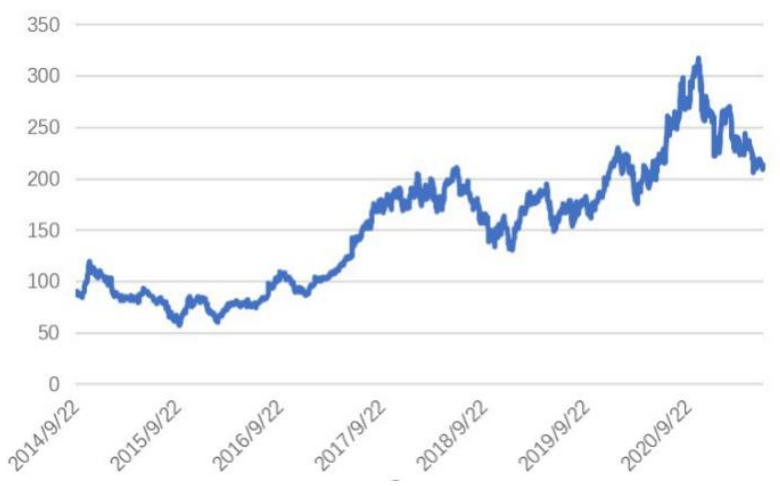

Figure 1. Alibaba's closing price

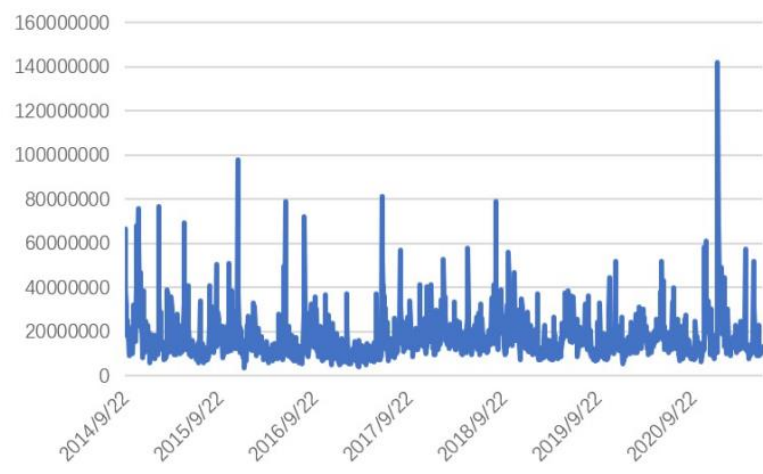

Figure 2. Alibaba's share volume

According to Figure 1, it can be seen that the stock price has maintained a rising state four years after Alibaba's listing, except for slight fluctuations and downturns, it has remained at 150-200 and above. Figure 2 clearly showed that the company's volume value changes, which are all fluctuations but reached a peak around October 2020, exceeding 140 million. Alibaba went public in September 2014. They learned from the previous lack of internal audits that caused the stock price to fall. There has been no substantial share price decline or problems arising from internal audits from the listing to the present. In addition, they also found a third party to help the company's internal audit.

\subsection{The case description}

On February 22, 2011, Alibaba's share price fell 8.47 percent on suspicion of commercial fraud. In the process, 1,219 Chinese suppliers signed up and 1,107 buyers defrauded the world, and the chief executive and chief operating officer resigned. The main reason here is also because of Alibaba's internal audit loopholes. In the first two years, Alibaba accounted for $1.1 \%$ and $0.8 \%$ of suppliers, which is decreasing year by year.

According to Alibaba B2B's third-quarter 2010 report, Alibaba's total revenue for the quarter was about 1,449 million yuan, with more than 1 million paid 
members and more than 56.7 million registered members. In the January-September quarter, Alibaba's revenue was RMB4,036 million, up 45.76 percent yearon-year, while net profit was about RMB1,060 million, up 44.7 percent. But from the first quarter of 2011, the results were very unsatisfactory.

However, it is believed that the company's longterm earnings growth is still positive and value-added services will continue to be the driving force for future performance. If synergies with Taobao are further strengthened, the pace of revenue contribution from value-added services will accelerate. As a result, the compound earnings growth for 2009-2012 is estimated to be $45 \%$, and the compound earnings growth for 2010 2013 is expected to be $38 \%$.

\subsection{The problem that occurred.}

In the process of internal trial, this problem is caused by the imperfection of the risk prevention system. Nearly 100 salespeople and some supervisors and sales managers are directly responsible for knowingly or negligently allowing fraudsters to circumvent the company's certification practices and for organized fraud in the international trading market. Alibaba has a certification process, but no third-party certification "levels" have been set up. Because in general, if you hire an independent third-party certification company, there will be cost implications, so many companies may not be willing to hire a certification company. In addition, written representations from the management; Evaluation on the management's certification disclosures about control over financial reporting [8].

Information systems provide both the means for organizations to transact business and the ability to report the financial results of their operations. Information technology auditing is an integral part of corporate governance. However, information technology auditing is often looked upon as a "necessary evil" or is overlooked entirely by IT management [9]. Alibaba's new chief executive said: "Based on our experience in anti-fraud investigations for retail companies, if a supplier wants to cheat, it is often only short-term fraud, and the damage is not significant." Because once there is feedback and reporting, it is not possible to carry on a long-term, large-scale basis. Judging by the time and scale of the Alibaba incident, it shows that its internal systems are not being audited and employee background checks are not being done enough.

Alibaba said the fraud involved an average payment of less than \$1,200 from the defrauded buyer. He pointed out that once the fraud occurred, the amount involved, the money and reputational damage to the company, and the costs of the relevant investigations are currently difficult to estimate. Alibaba's share price fell, and staff changes were mainly due to the company's lack of internal audit. Because they neither want to spend money to consult third-party audit firms, nor do they introduce new audit methods-information technology audits and complexity of the organization, business unit, or process, will play an important role in the Controls to monitor other controls, including activities of the internal audit function, the audit because of its importance to financial reporting and the auditor's opinions on internal control [10].

\section{RECOMMENDATIONS FOR ENTERPRISE IT SYSTEM AUDIT}

According to the above, there are several main problems: firstly, China lacks the technical talent of its audit. Secondly, some companies although they have their internal audit department but do not manage. Finally, some companies do not pay attention to audits. Based on the above questions, a few suggestions have been made.

\subsection{Complete IT system audit talent management}

In the audit process, IT audit personnel are also the key to the audit process. At present, there is no professional information system audit association in China, there is no professional examination to obtain its system audit qualifications, practitioners can only participate in is ACA organization's registered information system auditor (CISA) qualification examination to obtain certification. More professional ways should be added to train talents, such as company training or college study.

\subsection{Improve the management of IT systems.}

In the audit process, its system audit equipment perfection and system management are also essential. Information technology has been widely used by major enterprises, but the level of management within the enterprise does not agree. The company to improve the management level of IT systems, should start from the following aspects. First, the firm should develop a complete picture of the program, so that the internal thinking of the enterprise unity. Secondly, the enterprises should set up a separate IT audit-related department. The different departments should not be mixed within the enterprise's whole management.

\subsection{Pay attention to the internal audit department of the enterprise.}

When an enterprise uses IT systems as the primary audit method rather than a certified public accountant, they should pay more attention to the internal audit department. Enterprises should be more careful to select 
and IT audit-related knowledge or background of employees, so that a new enterprise quickly grasp the audit methods. Secondly, enterprises should regularly inspect and repair IT systems and conduct deeper training for employees.

\section{CONCLUSION}

The popularity of the Internet is a hotbed of computer-related crime. The growing problem of software project failures has raised questions about whether to audit the investment and development of information systems. IT audits have received unprecedented attention. This paper uses example analyses Alibaba's stock changes and studies the relationship between the company's stock decline and internal audit (information technology audit).

This article found that information technology audit and internal audits did not pay attention to the impact on the company. That could cause a serious drop in the firm's stock price and a replacement of its top management. This paper proposes three suggestions: most enterprises should keep a watchful eye on IT audit systems and train specialized talents. In addition, it has to pay close attention to the department of internal audit.

This article mainly uses the method of case analysis to discuss and describe, found that the lack of audit will cause the stock price decline and the company's main management will be replaced, but due to the lack of more cases and research, there is no way to accurately determine whether its audit is the most suitable and convenient audit method. In the future, it would collect more experimental results and more extensive dissemination to conducting research.

\section{REFERENCES}

[1] Gray, J. M. Information Technology Audits by Internal Auditors: Exploring the Evolution of Integrated IT Audits. Diss. Bentley University. 2016.

[2] Bazerman, M. H., G. Loewenstein, and D. A. Moore. "Why good accountants do bad audits." Harvard Business Review 80.11(2002):96-102.

[3] Janvrin, D, J. Biers taker, and D. J. Lowe "An Examination of Audit Information Technology Use and Perceived Importance." Accounting Horizons 22.1(2008):1-21.

[4] Bierstaker, J. L., Burnaby, P., \& Thibodeau, J.. (2001). The impact of information technology on the audit process: an assessment of the state of the art and implications for the future. Managerial Auditing Journal, 16(3), 159-164.
[5] Professional, R., \& Standards, P. (2007). An audit of internal control over financial reporting that is integrated with an audit of financial statements. AUDITING STANDARD No. 5.

[6] Stoel, D, D. Havelka, and J. W. Mahout. "An analysis of attributes that impact information technology audit quality: A study of IT and financial audit practitioners." International Journal of Accounting Information Systems 13.1(2012):6079.

[7] Kim, Hyo Jeong, M. Mannino, and R. J. Noachites. "Information technology acceptance in the internal audit profession: Impact of technology features and complexity." International Journal of Accounting Information Systems 10(2009).

[8] F Goldstein, et al. "An Audit of Internal Control over Financial Reporting Performed in Conjunction with an Audit of Financial Statements." Auditing Standard (2004).

[9] Mahout, J. W., \& Havelka, D. (2008). Information technology auditing: a value-added it governance partnership between it management and audit. Communications of Ais, 23.

[10] Views, S. (2007). An audit of internal control over financial reporting that is integrated with an audit of financial statements: guidance for auditors of smaller public companies. AUDITING STANDARD No. 5. 